Global Business Research Congress, May 30-31, 2019, Istanbul, Turkey.

\title{
DEVELOPMENT OF MARITIME MANAGEMENT AND MARITIME ECONOMICS
}

\author{
DOI: 10.17261/Pressacademia.2019.1099 \\ PAP- V.9-2019(46)-p.242-252
}

\section{Ergun Demirel ${ }^{1}$}

${ }^{1}$ Piri Reis University, Maritime Faculty, Istanbul, Turkey. edemirel@pirireis.edu.tr, ORCID: 0000-0002-6156-5850

\section{To cite this document}

Demirel E., (2019). Development of maritime management and maritime economics, PressAcademia Procedia (PAP), V.9, p.242-252

Permemant link to this document: http://doi.org/10.17261/Pressacademia.2019.1099

Copyright: Published by PressAcademia and limited licenced re-use rights only.

\section{ABSTRACT}

Purpose- Shipping is one of the most important elements of the World Economy. It takes place in almost every cycle of the supply chain from the supply of raw materials to the delivery of processed goods to the consumer. It is a very specific area of economic activity that presents the most international character in the world trade.

Methodology- Sea trade has a holistic structure embracing economy, business, politics, law, engineering and logistics associated with all other aspects of technologic, social and cultural aspects. The shipping concept should be considered worldwide basis and operates in according to both international and national regulations and practices.

Findings- As a result of technologic improvement the shipping is rapidly changing. The shipping business becomes more technical and it demands highly skilled and specialized management skills, procedures and process, ready to embrace continuously evolving technology. Conclusion- In this study it is intended to evaluate the future of the maritime management and maritime economics under the influence of digital era.

Keywords: Maritime management, maritime economics, digital era, shipping industry.

JEL Codes: M40, M41, M48

\section{DENIZ işLETMECIĞi VE DENIZCiLiK EKONOMISINDEKi GELIŞMELER}

\section{ÖZET}

Amaç- Denizcilik Dünya Ekonomisinin en önemli unsurlarından birisidir. Denizcilik tedarik zincirinin ham maddenin temin edilmesinden, üretilen malların tüketiciye ulaştırılmasına kadar olan her safhasında yer alır. Denzicilik ekonominin oldukça kendine özgü bir faaliyet alanı olup, Dünya ticareti içerisinde uluslararası bir karakter gösterir.

Yöntem- Deniz Ticareti ekonomi, iş dünyası, siyaset, hukuk, mühendislik, lojistik faaliyetlerin teknolojik, sosyal ve kültürel unsurlarını da kapsayan bütünleşik bir yapıya sahiptir. Denizcilik, Dünya bazında değerlendirilmesi gereken, hem ulusal hem de uluslararası düzenleme ve uygulamaları kapsayan bir konsepte sahiptir.

Bulgular- Teknolojik gelişmelerin bir sonucu olarak denizcilik de süratli bir değişim arz etmektedir. Denizcilik mesleği her gün süratle gelişmekte olan teknolojiyi takip edebilmek amacıyla, daha teknik bir özellik göstermekte ve oldukça yüksek yetenekli ve maharetli yönetim metotları ve uygulanmasını sağlayacak tekniklerin kullanılmasının gerektirmektedir.

Sonuç- Bu çalışmada dijital çağın etkileri ışığında deniz işletmeciliği ve denizcilik ekonomisinin gelecekte alacağı şekil değerlendirilmeye çalışılmaktadır.

Anahtar Kelimeler: Deniz işletmeciliği, denizcilik ekonomisi, dijital çağ, denizcilik endüstrisi JEL Kodları: M40, M41, M48 


\section{INTRODUCTION}

Shipping is one of the most important elements of the World Economy. It takes place in almost every cycle of the supply chain from the supply of raw materials to the delivery of processed goods to the consumer. It is a very specific area of economic activity that presents the most international character in the world trade. Total volumes of seaborne trade is reached 10.7 billion tons. It is expanding at 4 percent yearly and this trend will continue.

Sea trade has a holistic structure embracing economy, business, politics, law, engineering and logistics approximately associated with all other aspects of technologic, social and cultural aspects. The shipping concept should be considered worldwide basis, but its planning is to be made on regional basis and its implementation is to be conducted on a local / national basis. For this reason, in law, economics and logistics branches, sometimes shipping operates in according to both international and national regulations and practices. For these reasons, the interaction of shipping with all other sciences varies considerably.

The shipping provides all advantageous of economies of scale but it is should keep in mind that it may also show the character of the diseconomies of scale which may create surprizes for ship owners. Shipping is risk-laden and complex business. In all stages of the business planning, high priority should be given to the risk assessment.

The shipping is generally non-transparent area of activity and it is very hard to reach real data. For that reason the use of "second guessing (getting benefit from the ideas of others)" is important for decision making process.

Management aspects of shipping is generally considered in two branches as Marine Management and Marine Economy in international literature. In fact, it has common denominator with both the economy, management and business sciences. As such, it cannot be assumed to be a part of the economy or business science. The Maritime management and Marine Economics have their own independent institutes and scientific publications in the world. There are undergraduate, bachelor, master and doctoral level academic studies for both science in the world.

As a result of technologic improvement the shipping is rapidly changing. Digitalisation and high level automation lead important changes in the operation of maritime business and subsequently the reconsideration of the modus of operandi of shipping. The shipping business becomes more technical and it demands highly skilled and specialized management skills, procedures and process, ready to embrace continuously evolving technology.

In this study it is intended to evaluate the future of the maritime management and maritime economics under the influence of digital era taking into account, Automation of knowledge work, Advance Robotics, Autonomous vehicles, The internet of Things and Mobile internet.

\section{RESEARCH METHODOLOGY}

The aim of this study is to evaluate the future of the maritime management and maritime economics under the influence of digital era. The significant challenges such as automation, advance robotics, autonomous vehicles, internet of things and mobile internet will also be taken into account.

Meta synthesis is applied for this study. Reciprocal Translation method of meta-synthesis which is "Concepts in one study can incorporate those of another" is applied. Different approaches, considerations and predictions from versified sources are reviewed, evaluated and discussed to interpret the future of maritime management.

A meta- synthesis is bringing together qualitative data to form a new interpretation of the research field. It helps to build new theories and is not to be confused with a meta-analysis which tests a hypothesis using quantitative data. It primarily generates theory such as program theory, implementation theory, or an explanatory theory of why the intervention works or not, hypothesis for future testing or comparison with trial outcomes. Meta-syntheses are best designed for to re-interprets meaning across many qualitative studies (S. Atkins et al, 2008).

Maritime management has close relations with other modes of management. So it is believed that this study will also help other researcher to understand what will happen in the management science in the near future.

\section{REASEARCH}

\subsection{World Economy and World Seaborne Trade}

Global growth for 2018-19 is projected to remain steady at its 2017 level. Global growth is projected at 3.7 percent for2018-19 which is (-) 0.2 percentage point lower for 2017-2018. The downward revision reflects surprises that suppressed activity in early 2018 in some major advanced economies, the negative effects of the trade measures implemented or approved between April and mid-September, as well as a weaker outlook for some key emerging market and developing economies arising from country-specific factors, tighter financial conditions, geopolitical tensions, and higher oil import bills (WTO, 2018).

The change of World GDP was over $5 \%$ between 2004 and 2008 related to the high rate of GDP change in the Emerging economies. But a sudden drop is observed in the Economic (Financial) Crises at 2008. The negative effects of this crises started to change after 2008 and Change of GDP is stabilized at over 3\%. Since 2008 this GDP change is $3.8 \%$ and it is expected that figure will not be changed by 2023 (Figure 1). 
Figure 1: Change of the World GDP (Source: UNCTAD, 2018)

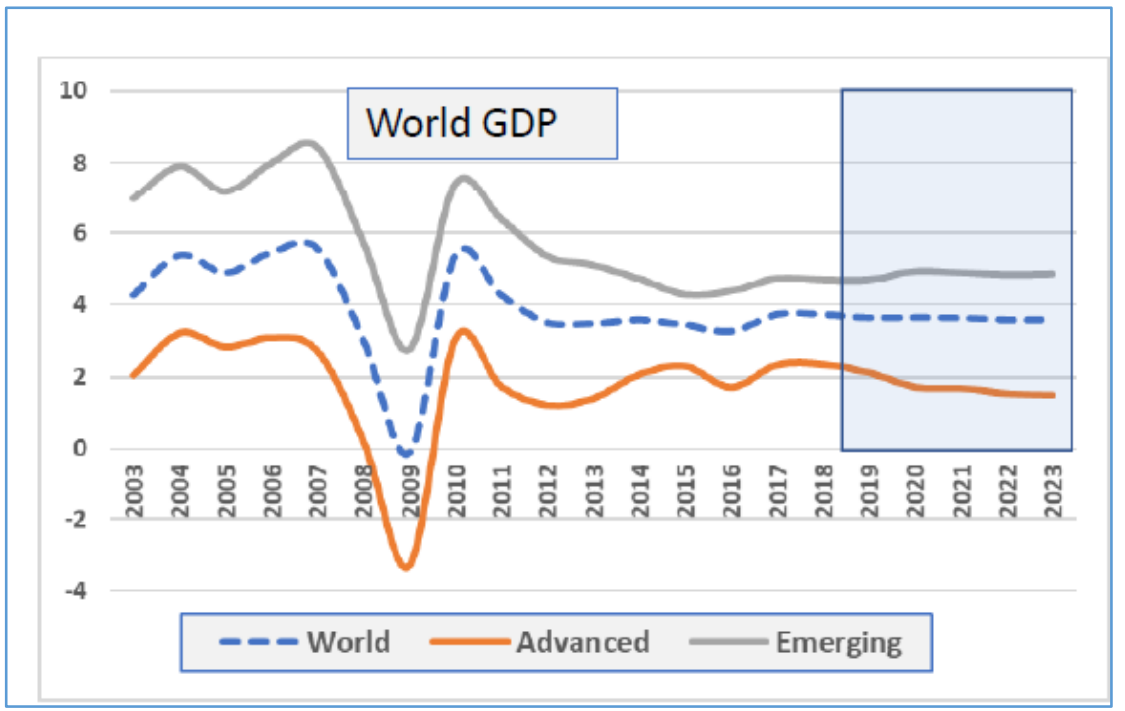

Global seaborne trade is doing well, supports by the 2017 upswing in world economy. Expanding at 4 percent, the fastest growth in five years, global maritime trade gathered momentum and raised sentiment in the shipping industry. Total volumes reached 10.7 billion tons, reflecting an additional 411 million tons, nearly half of which were made of dry bulk commodities (UNCTAD, 2018).

A significant increase is observed in containerized trade (6.4 percent) and dry bulk cargo (4 per cent), as crude oil is decelerated to 2.4 per cent. Prospects for seaborne trade are positive; UNCTAD (2018) projects volume increases of 4 percent in 2018, a rate equivalent to that of 2017. Contingent or continued favourable trends in global economy, UNCTAD is forecasting a 3.8 per cent compound annual growth rate between 2018 and 2023 (see Figure 2).

Figure 2: Change of Volume of Goods Traded (Source: UNCTAD, 2018)

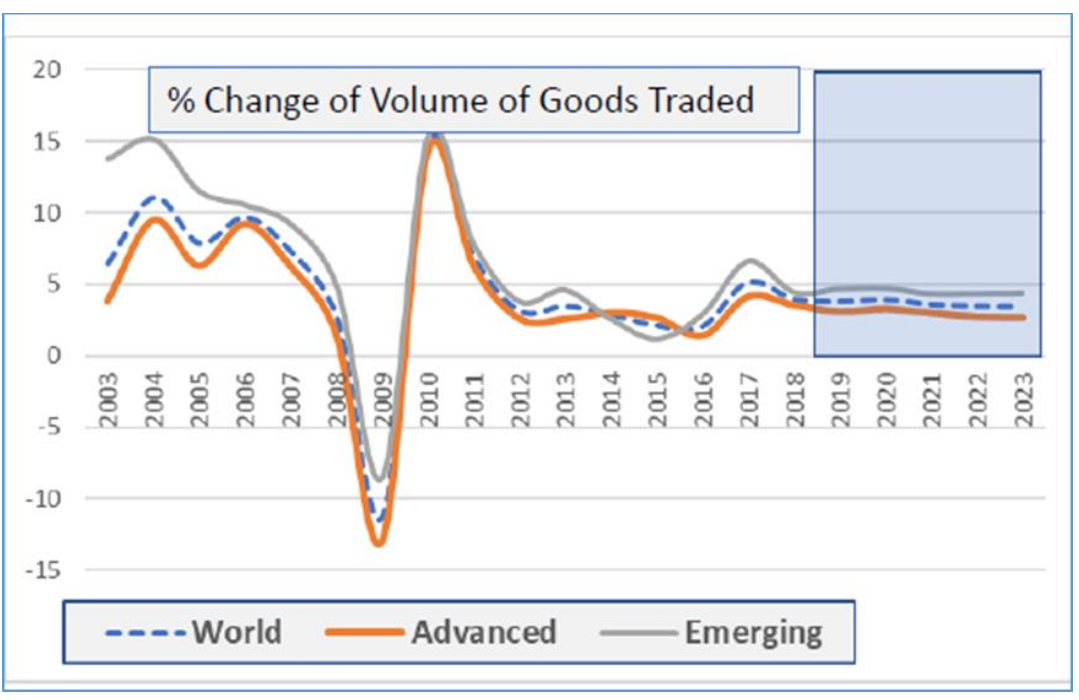

Martin Stopford has introduced a relation between freight rates and, ship construction and sales of which fright rates increase for 4 years and following 4 years decrease as and simultaneously the other two. And this trend has been valid for many years. However, related to the growth in the world economy since 1990s which increased from 2 to 4 percent changed this situation accordingly. The freight rates, which started to increase significantly in the beginning of 2000 and peaked till 2008. As a result of this misleading situation, shipbuilding investments have increased, and second hand ship prices have risen, making it impossible to find a new shipbuilding shipyard. With the financial / economic crisis that started in 2008 , freight rates suddenly fell to the bottom. This situation led to the collapse of many maritime companies. Stopford's trend has never been restored and the uncertainty and stability have been continuing for 10 years.

This situation has prompted marine operators to seek new methods. It is required to conduct a scientific research on a new trend for maritime transportation to enable the people to create a new concept to forecast the improvements which enable them make their midterm plans. 
The suggestion is to establish a method to estimate the growth in the Maritime transportation based on the growth in the world trade and world economy bases on reliable data. This application will better define the supply demand curve to estimate freight rate, future expectations on ship construction and ship sales.

Evaluation of last to decade: The average of the World Trade growth is 5.29 percent and growth of World GDP is 2.14 percent after deletion of 2 years which was related to the crises. That means the growth of World Trade is approximately 2.5 times bigger than growth of World GDP. The average of the Seaborne Trade growth is 4,154 percent and growth of World GDP is 2.14. That means the growth of Seaborne Trade is approximately 2.17 times bigger than growth of World GDP. There is a smooth rate relationship between GDP and Seaborne Trade. So, the growth of the World GDP can be used to predict the growth of the Seaborne Trade.

\subsection{Changes in the Maritime Industry}

The shipping industry has been widely changed as a result of the expansion of global trade, regional integration, multilateral and bilateral free trade agreements, and implementations of information and communication technology.

The historical process is dynamic, and the changes that occurred during the course of world shipping in the past century, embedded some of the structures of the nineteenth century (Harlaftis and Theotokas, 2015).

In this part it is intended to understand what changed in the maritime industry in the 21st century comparing with 20th century. It would be more reasonable first investigation changes in technology and companies as a part of shipping then changes in the shipping industry.

China and South Korea became significant maritime nations at the end of the 20th Century. The world maritime fleet boomed at the beginning of the 21st Century. The container transportation become more important and this improvement also developed both quality and quantity of intermodal transportation. China is now a driving force in the world economy as well as in the world shipping. Germany and China had taken important steps in container transportation not only the ships but also container terminals.

Branch (2007) focused on the following important issues which reshape the industry; Globalization of markets and product/manufacturing outsourcing; New markets through improved distribution networks through multi-modalism; Growth of multinationals through mergers and acquisition, thereby exploiting economies of scale; Continuous merger and formulation of operating alliances of major container operators, thereby contributing to developing more efficient distribution/ship productivity and accelerating the expansion of the global logistic hightech environment; Rapid development of technology and development in electronic commerce. This involves the development of electronic commerce to produce 'seamless' international trade transactions.

DNV GL (2017) made a study on the Shipping Traffic at 2016 tracked by fuel use for all types of ships. DNV GL has also made a calculation as based on AIS-use that values of this assumption is introduced in the Figure 3. Seaborne Trade Routes has changed between 2000 and 2016 depending upon the rise of the Chinese and Indian economies. As the Indian and Pacific Ocean trades grown a significant relative reduction in intercontinental traffic in the North Atlantic is happened. More than $60 \%$ of 2016 traffic is in Indian and Pacific waters, highlighting the importance of Asian trade. UNCTAD (2017) reports that Asia is the main importing and exporting region, accounting for $61 \%$ of unloaded cargo and $40 \%$ of loaded cargo in 2016. Developing economies are key players in supply of raw materials, but also growing sources of consumption import demand. In 2016, developing economies accounted for $63 \%$ of unloaded cargo and $61 \%$ of loaded cargo and developed economies $36 \%$ of unloaded cargo and $34 \%$ of loaded cargo. It is not expected a significant trade routes change unless an important change occurs in the emerging countries which may affect world economy.

Figure 3: Shipping Traffic 2016 Tracked by Fuel Use for all Types of Ships (DNV GL, 2017)

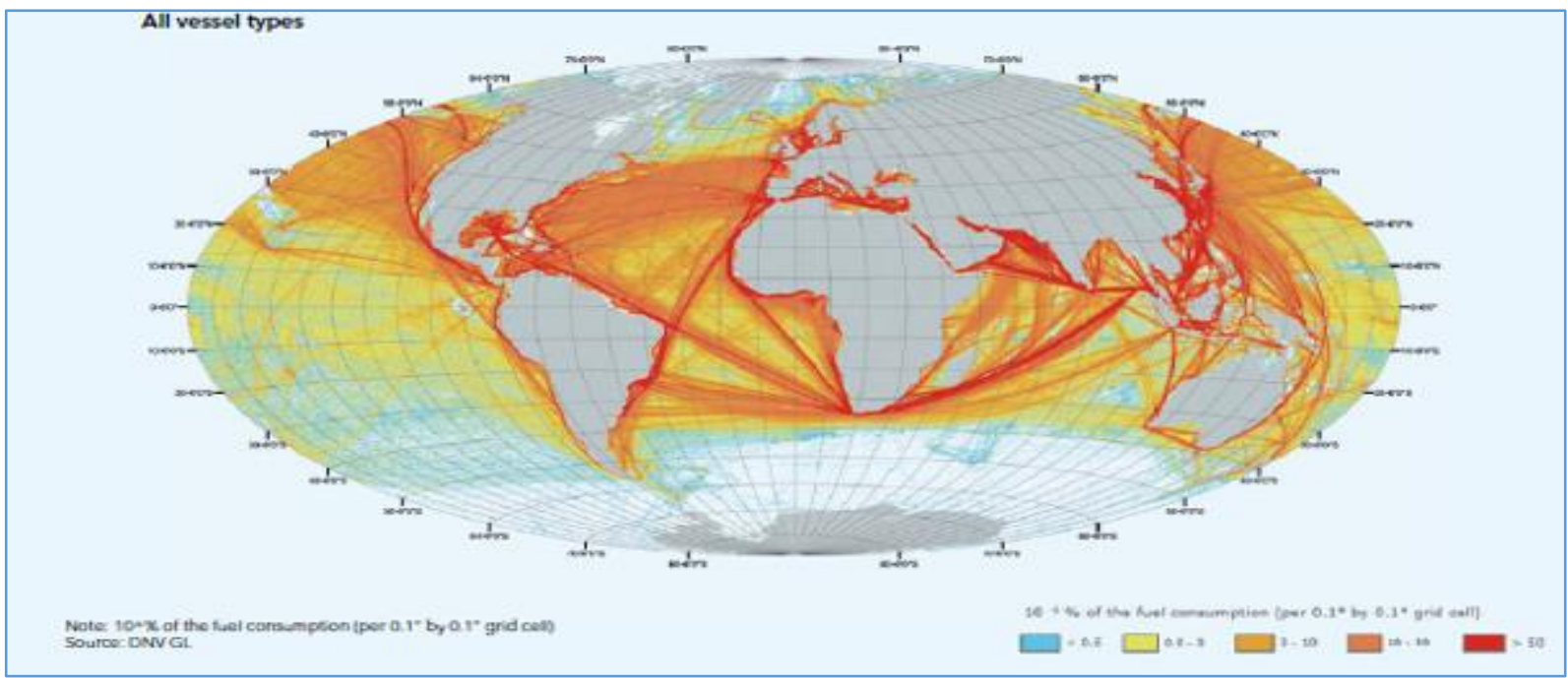


As far as concerning shipping companies mergers and amalgamations of big shipping companies created trusts in the world shipping. The INTERCARGO is empowered its control in bulk cargo transportation, as big patrol producers strengthen their control position on petroleum transportation through INTERTANKO.

After the introduction of container in 1960s the formation of shipping is highly changed. . This development resulted the re-structuring in the port systems of the various regions. Liner shipping is cumulated in the major ports and large ships and a requirement of feeder ships to transport commodities from major ports to small ports (feeder services) is raised. The competition between major shipping companies and local shipping companies transformed to a smooth cooperation.

Four main categories of bulk cargo are distinguished: the liquid bulk (crude oil, oil products and liquid chemicals), the five major bulk (iron ore, grain, coal, phosphates and bauxite), minor bulk (steel products, cement, sugar forest products etc.) and specialist bulk cargoes with specific handling or storage requirements (motor vehicles, refrigerated cargo, special cargoes). Gradually need adapted to demand, and the "tramp" ship was replaced by specialised ships that were built according to the bulk cargoes and the specialised bulk shipping markets; reefer ships for the refrigerated cargo, chemical tankers for chemical gases, LPG and LNG for liquefied petroleum and natural gas, heavy lift vessels for specific cargoes etc. (Harlaftis and Theotokas, 2015)

Nowadays "Global Liner Market" is leading the shipping. The main characteristic of new liner transportation are

- Emanation of huge shipping companies by the manner of mergers, acquisition and strategic alliances

- Vertical and horizontally integration of global and regional shipping companies serving global customers

Seaborne Trade Routes has changed. Indian and Pacific Ocean trades grown a significant relative reduction in intercontinental traffic in the North Atlantic is happened. More than 60\% of 2016 traffic is in Indian and Pacific waters, highlighting the importance of Asian trade.

Liner shipping is cumulated in the major ports and large ships. Global and regional shipping integrated both vertically and horizontally. Container transportation is becoming important and number and capacity of the container terminals are booming.

\subsection{Transition from Invention Era to Innovation Era}

19th and 20th Centuries were called as Invention Era to Innovation Era and 21st Century is probably called as Innovation Era. The biggest difference between invention and innovation is that as the emergence of invention is a burst, while the innovation is a continuous development. Innovation requires a well-organized continues efforts to develop existing tools and systems.

Madelin and D Ringrose (2016) explains world's new tools as in genomics and biotech, in data and materials, in energy and nutrition, in propulsion and cognition, in health and well-being, both physical and mental.

The shipping industry is closely related to the improvements in biotech, data, materials, energy in propulsion and cognition. All innovations in these fields quickly create influence in the shipping industry. As a consequence many change requires to make modification in organization, operation procedures and processes, regulations, education, technical aspects of shipping industry. This situation creates significant differences between the current structure and the structure 20 years ago.

The MET institution was reluctant in the research and development in the past. But innovation era is forced them to focus on research to respond innovation requirements for maritime sector. The composite maritime universities are appeared consist of not only maritime but also engineering, management and maritime science faculties supported with master and doctoral studies and research centres.

Innovation is an inevitable issue for maritime sector to adopt new technologies and sustain in the challenging economy. Maritime research centres either independent or embedded in universities are now a requirement for the sector.

\subsection{What Is Changing in Management}

Disrupt or be disruptive is a new mantra of sustainability. Zero emissions; fixed price electricity from clean energy sources; ultra-efficient domestic temperature control requiring just five percent of energy required for conventional systems; these are all examples of disruptive sustainability. Similar thinking and approaches are being applied in the shipping industry. Companies are looking for at sustainability issues and seeing disruptive threats that are pushing them to make transformational changes. Addressing the problems facing the shipping industry in the $21^{\text {st }}$ century requires entirely new thinking (Mulligan, 2016).

It is clear that companies cannot continue to operate in a 'business-as-usual' manner as our world changes under the new form of growing economy which is the driving force of the shipping. Not only change of business-making styles, but also structure of the companies are changing with new partnerships, consortiums and mergers. Nowadays many companies entered different business sectors which are not related with their main area of activity. Especially giant IT sector companies started to involves with other business areas. Amazon is now taking steps into the shipping business, as Google entering travel sector. Shipping companies making mergers, becoming huge logistics companies, operating ports and owning shipyards. That makes big changes in the organization and modus operandi of these companies.

Reducing cost and boost efficiency are the major problem area in today's shipping in the challenging world economy. Rhodes and Scott (2014) draws attention of shipping sector in two major area related to the cost and efficiency; Search for Alternatives for Fuel and Better Data for Ensuring Efficiency. The biggest headache for is the inexorable rise in costs of fuel and compliance with new regulatory requirements. Fuel currently accounts for more than half of daily shipping operations. One of the major inhibiting factors in achieving greater efficiencies in ship operations is the paucity of data flowing from shore to ship. The shipping companies is in need of a huge budget for ITC expenses to ensure shore to ship communication flow and handle management systems. 
The material used on board and ports are changing. Ultrahigh Molecular Weight Poly-Ethylene fibre is now used in heavy lifting equipment. Materia used ship construction is rapidly changing to reduce the weight and facilitate maintenance which is also a serious cost for shipping industry. Innovation in the material and enhance use of automation is changing the operation and maintenance systems on board.

Maritime Sector is a part of supply chain. The area of interests of supply chain management is changing. The following agenda items of Next Generation Supply Chain Conference held Chicago on 16 April gives clear idea about these change;

- Applying Augmented Intelligence (A.I.), Blockchain and Predictive

- Analytics to Expand End-to-End Visibility and Improve Operational Efficiency

- The Digital Supply Chain Transformation

- Robotic Panel Sessions and Presentation

- The Real Value of Robots: How Users in New Markets are

- Benefiting from Robots

- Piece Picking Robotics

- Mobile Robotics

Performance Management, Capacity Optimization and Knowledge Management become rather important functions in the all elements of shipping, in particular in the ship management and shipbuilding.

Companies are looking for at sustainability issues and seeing disruptive threats that are pushing them to make transformational changes. Addressing the problems facing the shipping industry in the 21st century requires entirely new thinking.

Reducing cost and boost efficiency are the major problem area in today's shipping in the challenging world economy.

The shipping companies is in need of a huge budget for ITC expenses to ensure shore to ship communication flow and handle management systems.

Innovation in the material and enhance use of automation is changing the operation and maintenance systems on board. Augmented Intelligence (A.I.), Blockchain and Predictive Methods, Improvement of Operational Efficiency Digital Supply Chain Transformation, Robotic, Expanded analytics are the new areas which should be considered.

The main actors of shipping sector cannot continue to operate in a 'business-as-usual' manner as the world is changing under the high pressure of rapid change of technology. Participation to diversified job areas changes organization and management systems of the companies in the sector

\subsection{Exponential Development and Exponential Management}

As a result of the development of high technology in the last quarter of the 20th century, the trend of technological development changed from linear to exponential. The figure taken from the web pages of Dr Ed Forrest well explains this situation. Unfortunately our way of thinking and business attitude a are still working in linear manner. This creates reaction a disruption between the real situation and our reaction which may cause wrong decisions (Figure 4).

Figure 4: Linear vs. Exponential (Source: Forrest, 2016)

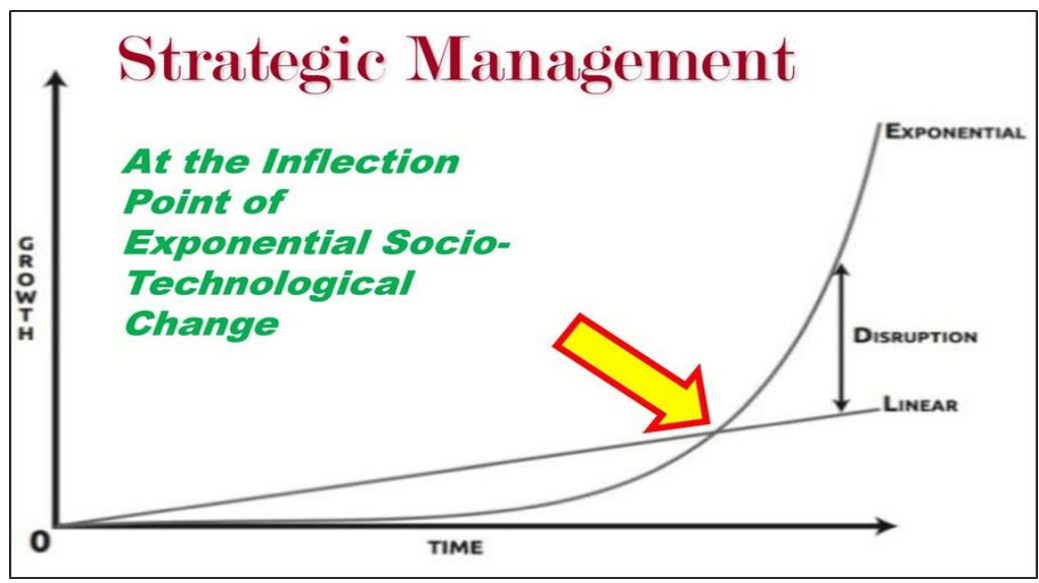

Unfortunately, organizations and business management methods are late in tracking this trend. One of today's emerging approaches is the rise of 'exponential management'. This new approach has affected the maritime management field, like all other management forms. 
In the exponential mind-set, managers replace control of people with control of principles. The use of doctrine to guide decision-making generates alignment, consistency and empowerment. But most leaders are accustomed to making decisions rather than empowering decisions (Bonchek, 2016).

Famous futurist Leonhard (2015) said "Humanity will change more in the next 20 years than in the previous 300 years". The maritime management needs to adopt exponential mind-set to secure the management maritime industry which engines 90 percent of the global economy.

One of today's emerging approaches is the rise of 'exponential management'. This new approach has affected the maritime management field, like all other management forms.

\subsection{New Approaches in the Management}

The competition became rather important in the challenging global economy which requires quick perception of the situation and taking rapid responses. As a result of this new approach management skills of the managers become momentous. The following specifications are expected from managers;

- Clear understanding of role of the company

- Matching the competencies of managers to the role of the company

- Ability to respond problems quickly

- Building rapport with customers and employees

- Diligent research on market

A new strategic management concepts has been introduced, namely Stakeholders Approach. The stakeholder concept can be useful in integrating some of these issues (plans and systems of the plans for business level entities, role of the corporation in the social systems, social responsibility of the business, behaviour of the large group of the populations of the organizations and their environments) around the concept of organization strategy, that is around the issues of how organizations can configure themselves and take actions to align themselves with the environment (Freeman, 2011). We are living in a rapidly changing world which needs to be adopted new system approaches to be able start to challenge in the competitive maritime market.

The composition of high level management is changed under the influences of strategic management; not only shareholders but also stake holders are incorporated in the management boards. Old style CEOs are replaced with young, well educated, communicative managers endowed with high technology and capable to establish with society.

The shipping companies were generally led by family members. But changing business environment enforced them to change this manner and leave the rudder to professional managers. Mergers, differentiation and diversification of business area they deployed CEOs from different sectors. Nonstop evolution of the economy required change of the mangers every 4-5 years. The era of life-time CEOs is finished. Easy air transportation and improved communication finished management from the office and nowadays managers are like flying tourists to reach all interested points in the world as well as middle management.

Any strategic management model must deal with a number of key questions. The questions listed below are some which can be understood partially in stakeholder terms (Demirel, 2015):

- Strategic Direction (Direction or mission of organization)

- Strategic Programme Formulation (Paths of strategies)

- Budgeting (Resource allocation for application of the strategy)

- Control (To be sure that the strategies are on the track)

- Structure and System (Macro systems and structures for implementation)

The Germanischer Lloyd and Fraunhofer CML (2014) conducted a large scale study involving 100 ship management companies across the globe to find what they are doing to improve their operation and what they consider as best practices in the industry. The companies have explained that their biggest challenges of ship management in mid-term future in five areas; Crewing (88\%), Technical Management (62\%), Financial Management (\%50), Quality and Safety (\%27) and procurement (12\%).

The strategic planning, human resources (crew management), finance, quality and safety management and procurement became significant functions and they are now independent branches directly reporting to CEO.

Martin Stopford (2015) explains the expected changes in the managements follows:

- The maritime business model can change

- Marine technology is running out of solutions

- Smart -Shipping offers a new business model 
- Other transport industries are already doing it

The composition of high level management is changed under the influences of strategic management; not only shareholders but also stake holders are incorporated in the management boards. Old style CEOs are replaced with young, well educated, communicative managers endowed with high technology and capable to establish rapport with society.

Strategic planning, human resources (crew management), finance, quality and safety management and procurement became significant functions and more importance should be given to these branches.

\subsection{Changes in the Shipping related to the Technology}

Technology is reshaping the shipping and this trend will transform shipping into new domains. The environmental concerns of the society enhance and there increasing demand of society for urgent measures to protect environment forces all industries to take steps to stop the environmental pollution. The shipping industry which engines approximately $90 \%$ of global trade is under this pressure. The classical "productivity, cost and operational efficiency" approaches should be reconsidered under the pressure of environmental and sustainability concerns. It will change traditional business models, companies structure and management procedures. The maritime companies need to adapt new management models to survive and sustain their business.

Clyde \& Co (2017) and IMarEST teamed up in a joint initiative to seek insight on emerging technologies from more than 20,000 marine professionals around the world. Within this report they have provided an overview of the impact of emerging technologies today and identify the market's key concerns regarding operating, staffing, insuring and implementing emerging technologies in the shipping sector. In according this report the following technologies will show the most growth in the next 10 year;

- Smart shipping: Most respondents forecast the introduction of smart shipping in the next $10-15$ years. $75 \%$ of respondents believe smart shipping will impact their business.

- Energy management: $73 \%$ believe fuel availability will strongly drive the market's decision to adopt alternative energy management solutions. Other notable drivers included heavy fuel oil (HFO) price and the capital and/or infrastructural investment required to support alternatives. The top ranked advantages of energy management solutions include reduced fuel consumption, enhanced efficiency, and improved corporate reputation and optimised operational profile.

- Green technologies: $67 \%$ believe differences in regional and international regulation will impede adoption. Respondents were divided on how difficult it will be to assess the available solutions for compliance with the $0.50 \% \mathrm{~m} / \mathrm{m}$ IMO sulphur limit. For most, the adoption of green technologies is driven by compliance, particularly for vessels sailing in waters covered by regional and global rules. The availability of adequate bunkering infrastructure concerns some operators exploring switching vessels to LNG/LPG.

The protection of the environment has now become a topical issue and recent IMO initiatives with regards to reducing waste and pollution such as 'Ships Recycling, Green-House Gas Emissions from Ships (GHG), Special and Particularly Sensitive Sea Areas, Control and Management of Ship's Ballast Water and Sediments, etc.' will provide ample opportunities and catalysts for MET institutions to review their provisions while at the same time incorporating the changes in STCW requirements (Ziarati et al, 2010).

The commercial benefits of better energy management mean vessel operators and other stakeholders are almost without exception closely monitoring developments. Respondents emphasised the need to keep abreast of the evolving regulatory landscape for alternative power arrangements. The majority of respondents don't recognise regulation as a hindrance to adopting fuel alternatives but recognise there should be a focus on crew and shore based personnel to have the necessary competencies to safely use and maintain new equipment.

After the introduction of container in 1960s the formation of shipping is highly changed. This development resulted the re-structuring in the port systems of the various regions. Liner shipping is cumulated in the major ports and large ships and a requirement of feeder ships to transport commodities from major ports to small ports (feeder services) is raised. The competition between major shipping companies and local shipping companies transformed to a smooth cooperation.

Four main categories of bulk cargo are distinguished: the liquid bulk (crude oil, oil products and liquid chemicals), the five major bulk (iron ore, grain, coal, phosphates and bauxite), minor bulk (steel products, cement, sugar forest products etc.) and specialist bulk cargoes with specific handling or storage requirements (motor vehicles, refrigerated cargo, special cargoes). Gradually need adapted to demand, and the "tramp" ship was replaced by specialised ships that were built according to the bulk cargoes and the specialised bulk shipping markets; reefer ships for the refrigerated cargo, chemical tankers for chemical gases, LPG and LNG for liquefied petroleum and natural gas, heavy lift vessels for specific cargoes etc. (Harlaftis and Theotokas, 2015).

Nowadays Global Liner Market is leading the shipping. The main characteristic of new liner transportation are;

- Emanation of huge shipping companies by the manner of mergers, acquisition and strategic alliances

- Vertical and horizontally integration of global and regional shipping companies serving global customers

Productivity, cost and operational efficiency concepts should be reconsidered under the pressure of environmental and sustainability concerns. Traditional business models, structure and management procedures of the companies should be reviewed and revised to survive in the challenging market.

Introduction of smart shipping, more interest on Energy management and green shipping is expected.in the next 10-15 years.

Emanation of huge shipping companies and vertical and horizontally integration of global and regional shipping is expected to be continued. 


\subsection{The Future Roles of Shipping Companies}

First an important aspect of shipping companies was their connection with a specific home port; second was the ownership and management of the company by distinct families for multiple generations; third was the use of a regional network for drawing investment funds, and fourth was the existence of an international network of overseas agencies that collaborated closely with trading houses on a particular oceanic region, or on a particular commodity trade (Harlaftis and Theotokas, 2015).

The following factors/conditions of new era should be taken into consideration for organizational change or transformation in shipping companies;

$$
\begin{aligned}
& \text { Not only local or regional but also international competition } \\
& \text { Wide use of alternative business system } \\
& \text { Understanding the role of competition in fostering innovation } \\
& \text { Collaboration with others in addition to cooperation and coordination } \\
& \text { Taking into account speedy change in technology } \\
& \text { Making transformation rather than modification or minor changes }
\end{aligned}
$$

The shipping companies may also be assumed as a logistic company as a nature of the work. The logistic companies have different entities from a regular organization and cover two groups of departments: Logistic Departments (Export-Import, Fleet Management, Operations, AirSea-Road-Rail Transportation, Customs, and Insurance etc.) and General Management departments (Marketing, H/R, Accounting, Administration, IT, Purchase, Quality Management etc.) (Erdal and Saygili, 2007). But only a few companies have been organized in this manner and not eligible to assume a logistic company responsibility. This is a factor which may hamper their improvement for future roles.

In order to survive in economic crises, shipping companies should they should diversify their business areas and consider international competition for planning purposes.

The huge worldwide shipping companies are dominating the sectors when the number of the small shipping companies reduces. This also changes organization and operation styles of the shipping companies with enhanced headquarters and branches throughout the world.

Innovation gains importance to be successful in the challenging world economy. They should establish collaborate with others by establishing consortiums and strategic partnership.

In order to keep step with speedy change in technology, they should make transformation rather than modification or minor changes in their modus operandi.

\section{CONCLUSION}

\subsection{General}

Shipping is risk-laden and complex business. In all stages of the business planning, high priority should be given to the risk assessment and management. The shipping provides all advantageous of economies of scale but it is should keep in mind that it may also show character of the diseconomies of scale which may create surprizes for ship owners.

The shipping is generally non-transparent area of activity and it is very hard to reach real data. For that reason 1secon guessing (getting benefit from the ideas of others) is important for decision making.

There is a smooth rate relationship between growth of GDP and Seaborne Trade. The growth of Seaborne Trade is approximately 2.17 times bigger than growth of World GDP. So, the growth of the World GDP can be used to predict the growth of the Seaborne Trade.

\subsection{Effects of Technology on Maritime Business}

Innovation is an inevitable issue for maritime sector to adopt new technologies and sustain in the challenging economy. Maritime research centres either independent or embedded in universities are now a requirement for the sector. Innovation in the material and enhance use of automation is changing the operation and maintenance systems on board. Augmented Intelligence (A.I.), Blockchain and Predictive Methods, Improvement of Operational Efficiency Digital Supply Chain Transformation, Robotic, Expanded analytics are the new areas which strongly affects the maritime sector.

Introduction of smart shipping, more interest on energy management and green shipping is expected.in the next decade.

In order to keep step with exponentially change in technology, the maritime sector should make transformation rather than modification or minor changes in their modus operandi.

\subsection{New Posture of Shipping}

Liner shipping is now the driving force of the seaborne trade. Container transportation is becoming important and number and capacity of the container terminals are booming. 
Emanation of huge shipping companies and vertical and horizontally integration of global and regional shipping is expected to be continued. Shipping companies should consider international competition for planning. In order to survive in economic crises they should diversify their business areas. They should establish collaborate with others by establishing consortiums and strategic partnership.

\subsection{Management Concept}

One of today's emerging approaches is the rise of 'exponential management'. This new approach has affected the maritime management field, like all other management forms.

The composition of high level management is changed under the influences of strategic management; not only shareholders but also stake holders are incorporated in the management boards. Old style CEOs are replaced with young, well educated, communicative managers endowed with high technology and capable to establish rapport with society.

Strategic planning, human resources (crew management), finance, quality and safety management and procurement became significant functions and more importance should be given to these branches.

Productivity, cost and operational efficiency concepts should be reconsidered under the pressure of environmental and sustainability concerns. Traditional business models, structure and management procedures of the companies should be reviewed and revised to survive in the challenging market.

\subsection{Shipping Companies}

Companies are looking for at sustainability issues and seeing disruptive threats that are pushing them to make transformational changes. The problems facing the shipping industry in the 21 st century requires entirely new thinking.

The main actors of shipping sector cannot continue to operate in a 'business-as-usual' manner as the world is changing under the high pressure of rapid change of technology. Participation to diversified job areas changes organization and management systems of the companies in the sector.

Reducing cost and boost efficiency are the major problem area in today's shipping in the challenging world economy. The shipping companies is in need of a huge budget for ITC expenses to ensure shore to ship communication flow and handle management systems.

\subsection{Organizational Changes}

The huge worldwide shipping companies are dominating the sectors when the number of the small shipping companies reduces. This also changes organization and operation styles of the shipping companies with enhanced headquarters and branches throughout the world.

Strategic planning, human resources (crew management), finance, quality and safety management and procurement became significant functions and more importance should be given to these branches.

\section{REFERENCES}

Atkins S., Lewin S., Smith H., Engel M., Fretheim A., Volmink J., (2008). Conducting a meta ethnography of qualitative literature: lessons learnt, BMC Med Res Methodol. Apr; 8:21. doi: 10.1186/1471-2288-8-21.

Branch A. E., (2007). Elements of Shipping, 8th Edition, Taylor \& Francis -Routledge, London, ISBN 978-0-41 5-36286

Clyde \& Co, (2017). Technology in shipping; The impact of technological change on the shipping industry, J405575 - November 2017

Demirel E.. (2015). A study on the organization and management systems of Turkish shipping companies, International Journal of Human Sciences (JHS) ISSN: 2458-9489 Volume: 12 Issue: 2 Year: 2015

Erdal M. and Saygili M., (2007). Management- Organization and Fleet Management at the Logistic Companies (Lojistik Isletmelerinde Yonetim-Organizasyon ve Filo Yonetimi), Zebra Matbaacılik ve Baski Hizmetleri A.S., Istanbul ISBN 978-975-92469-6-9

DNV GL, (2017). Maritime Forecast to 2050, Safer Smarter Green. Energy Transition Outlook 2017, DNV GL AS No-1322 Høvik, Norway

Forrest E., Strategic Management, At the Infection Point of Exponential Scio-Technological Change, Retrieved from https://slideplayer.com/slide/12877941/ (Entered: 1 April 2019)

Freeman R.E., (2011). Strategic Management, Cambridge Press, Noida ISBN -13 978-107-16851-0 p.43, 45

Fraunhofer CML and GL, (2014). Best Practice Ship Management Study 2013, GL Maritime Software Product, Hamburg OE845-2013-04-01 p. 2,6

Harlaftis G. and Theotokas I., (2015). Maritime Business during the Twentieth Century: Continuity and Change, Law Explorer/MARITIME LAW, Retrieved from https://lawexplores.com/maritime-business-during-the-twentieth-century-continuity-and-change/ (Entered: 11 April 2019) 
Leonhard G. (2015). Digital Transformation, Keynote Speech, 29th World Ports, Shipping and Maritime Conference, Hamburg 2015

Mark Bonchek M., (2016) How to Create an Exponential Mindset, STRATEGIC THINKING, Harvard Business Review https://hbr.org/2016/07/how-to-create-an-exponential-mindset (Entered on 10.04.2019)

Mulligan T., (2016). Disruptive Sustainability, Maritime Reporter and Engineering News, April 2016 ISBN: 0025-3448

Rhodes J and Scott F., (2014). Shipping Companies Must Reduce Costs and Boost Efficiency, Maritime Reporter and Engineering News, April 2014 ISBN: 0025-3448

Stopford M., (2006). Maritime Economics, 6th Edition, Routledge - Taylor \& Francis Group, London ISBN 0-203-44266-0

Stopford M., (2015). Maritime Strategy - The Fourth Wave. Maritime Shipping, Clarkson Research, Retrieved from https://www.city.ac.uk/_data/assets/pdf_file/0009/289197/OL-Stopford,-M..pdf (Entered: 02 April 2019)

UNCTAD, (2018). Maritime Transportation 2018, ISBN 978-92-1-112928-1 elSBN: 978-92-1-047241-8 ISSN 0566-7682

WTO, (2018). Press/820 Press Release, Strong trade growth in 2018 rests on policy choices, Retrieved from (https://www.wto.org/english/news_e/pres18_e/pr820_e.htm (Entered: 02 April2019)

Ziarati R., Demirel E., Albayrak T., (2010). Innovation in Maritime Education and Training, IMLA 2016 Proceedings, İzmir ISBN 978-975-441256-7 